\title{
De sociale basis van politieke rekrutering
}

\section{Een vergelijkende studie van gemeenteraadsleden in Europa}

\author{
Herwig Reynaert, Tom Verhelst en Kristof Steyvers
}

\begin{abstract}
SAMENVATTING VAN:
Reynaert, H., Verhelst, T. \& Steyvers, K. (2012), The Social Base of Political Recruitment. A Comparative Study of Local Councillors in Europe, Lex Localis, Journal of Local Self Government, 10 (1), 19-36.
\end{abstract}

In de literatuur richt men zich vaak op de sociale achtergrond van lokale politieke elites om hun selectieve rekruteringsproces te verklaren (Steyvers \& Reynaert, 2006, pp. 43-48). Ondanks belangrijke evoluties en verschillen tussen politieke systemen komt daarbij doorgaans een disproportionele rekrutering van bepaalde sociale groepen aan de oppervlakte. Zo blijken lokale politici vaker van het mannelijke geslacht en middelbare leeftijd. Ze zijn doorgaans ook hoog opgeleid en bogen dikwijls op een hoge professionele status en een beroepsachtergrond compatibel met politiek (Eldersveld, Stromberg \& Derksen, 1995, pp. 31-55). Het politieke rekruteringsproces werkt dus niet neutraal. Integendeel, de selectie van het politiek personeel vergroot de kansen van individuen met bepaalde kenmerken om een politiek mandaat te verkrijgen en te behouden. De centrale onderzoeksvraag in rekruteringsonderzoek luidt daarom: wat zijn deze ken- merken en hoe beïnvloeden ze het selectieproces?

Dit artikel zoekt een antwoord op deze vraag door de achtergrondkenmerken van 11.962 gemeenteraadsleden uit 16 landen te vergelijken. ${ }^{1}$ De data werden verzameld op basis van een standaard-postenquête die in de context van het Europese onderzoeksproject MAELG (Municipal Assemblies in European Local Governance) werd ontwikkeld. De verschillende culturele en structurele bestuurstradities die in het onderzoek zijn opgenomen laten ons toe om een systematisch inzicht te verkrijgen in de basis van het rekruteringsproces binnen de verschillende landen en over de landsgrenzen heen. In onze studie analyseren we zes specifieke achtergrondkenmerken: geslacht, leeftijd, opleiding, beroep, afkomst en lokale 'roots'. Deze focus houdt uiteraard een aantal beperkingen in. We blijven immers niet stilstaan bij diegenen die eenzelfde profiel hebben maar geen mandataris zijn. Nochtans zou 
het ook interessant zijn om na te gaan waarom sommigen met eenzelfde profiel uiteindelijk geen dergelijk mandaat uitoefenen. Ook complementaire fasen uit het rekruteringsproces (bijvoorbeeld politieke activering en leerscholen) komen hier niet aan bod (maar wel in andere artikelen) van het special issue waarvan dit artikel een onderdeel is.

"To be a man or not to be a man": dit is traditioneel een belangrijke vraag in rekruteringsonderzoek. Het antwoord op deze vraag is vrij eenvoudig. Gemiddeld is bijna $73 \%$ van de raadsleden een man. In Polen, Griekenland, Italië en Israël is dit zelfs meer dan $80 \%$. Vrouwen hebben dan weer duidelijk meer kansen in Frankrijk, Zweden en Noorwegen: hier vinden we respectievelijk 'slechts' 54,5\%, 57,1\% en $61,4 \%$ mannen in de raad. Het genderonevenwicht is dus zeker niet van de baan. Lokale politiek blijft een door mannen gedomineerde activiteit.

Een tweede klassieke variabele is de leeftijd van de raadsleden. We stellen vast dat de gemiddelde leeftijd van 51,1 jaar het traditionele patroon bevestigt. De gemiddelden variëren bovendien niet sterk tussen de landen. Raadsleden zijn gemiddeld het jongst in Spanje $(45,2)$, Zwitserland $(47,8)$ en Italië $(48,3)$ en het oudst in het Verenigd Koninkrijk $(58,6)$, Zweden $(54,2)$ en Duitsland $(54,1)$.

Vervolgens vroegen we naar het opleidingsniveau - het hoogst behaalde diploma - van de raadsleden. Het is duidelijk een voordeel als men een universitair diploma heeft: $62,7 \%$ van de raadsleden had een universitair diploma op het moment dat ze een lokaal mandaat opnamen. Wel is de spreiding over de landen ruimer.
In bepaalde landen stijgt dit percentage tot boven 70\% (Israël, Frankrijk, Verenigd Koninkrijk en Spanje), terwijl het in andere onder $50 \%$ ligt (Italië, Oostenrijk en Zweden).

Als vierde kenmerk analyseren we welk beroep de raadsleden uitoefenden vooraleer ze hun eerste lokaal politiek mandaat opnamen. In het algemeen oefende ruim de helft van de raadsleden een selectief of geprivilegieerd beroep uit voor dit eerste mandaat (professionele politicus, ambtenaar, leerkracht, zakenman, vrij beroep). ${ }^{2}$ In Griekenland en het Verenigd Koninkrijk is deze selectiviteit nog veel sterker aanwezig (respectievelijk 65,1\% en 67,3\%), in België, Kroatië, Oostenrijk en Zweden bogen minder raadsleden op een dergelijke selectieve beroepsachtergrond (41,6\%, $39,7 \%, 40,7 \%$ en $42,4 \%$ ).

Waar zijn de raadsleden en hun ouders geboren? Van zodra het raadslid, de moeder of de vader in een ander land is geboren, beschouwen we het raadslid van 'vreemde afkomst'. Globaal is dit voor $15,2 \%$ van de raadsleden het geval. Er is echter één heel opvallend cijfer. Slechts $9,8 \%$ van de raadsleden in Israël heeft geen vreemde afkomst. Dit heeft uiteraard te maken met het feit dat heel wat ouders van die raadsleden elders werden geboren, omdat Israël op dat moment nog niet bestond. Ook voor Kroatië en Tsjechië moeten we rekening houden met de specifieke situatie van deze landen. In Italië $(3,2 \%)$ en Spanje $(3,1 \%)$ is het aandeel raadsleden van vreemde afkomst miniem. Zwitserland (21,5\%) en Frankrijk (17,5\%) scoren ten slotte boven het gemiddelde.

De laatste variabele in onze studie is lokale 'roots'. Raadsleden die reeds voor 
hun $18^{\text {de }}$ levensjaar in hun gemeente woonden, kennen we lokale 'roots' toe. We stellen vast dat gemiddeld meer dan de helft van de raadsleden lokale 'roots' heeft. In België, Griekenland, Italië en Kroatië is dit zelfs voor meer dan 7 op 10 raadsleden het geval. Een sterke verankering in de gemeente blijkt anderzijds minder belangrijk in Frankrijk, Nederland en het Verenigd Koninkrijk (28,4\%, 35,5\% en $29,2 \%$ ).

Op basis van onze analyse kunnen we zo concluderen dat het rekruteringsproces de mogelijkheden van individuen om raadslid te worden inderdaad verhoogt als men over bepaalde selectieve achtergrondkenmerken beschikt. Gemeenteraadsleden zijn nog steeds vaker man, van middelbare leeftijd en hoog opgeleid. Ze hebben doorgaans een selectieve beroepsachtergrond en lokale 'roots'. Raadsleden van vreemde origine komen minder vaak voor. De vergelijkende aard van het onderzoek laat ons toe om dit algemene beeld te nuanceren: er zijn namelijk duidelijke verschillen tussen de raadsleden van de 16 landen al naargelang het kenmerk dat we bestuderen. Systematische patronen vallen echter moeilijk te ontwaren. ${ }^{3}$ Voor Polen, Kroatië en Tsjechië kunnen we nog min of meer een gelijkaardig en gemiddeld patroon waarnemen. Voor de Franco-groep (Frankrijk, Italië, België, Griekenland en Spanje) en de Noord- en Midden-Europese groep (Duitsland, Nederland, Oostenrijk, Zwitserland, Zweden en Noorwegen) zijn de gelijkenissen echter niet zo duidelijk. ${ }^{4}$

\section{Noten}

1. De 16 landen zijn, in alfabetische volgorde: België, Duitsland, Frankrijk, Griekenland, Israël, Italië, Kroatië, Nederland, Noorwegen, Oostenrijk, Polen, Spanje, Tsjechië, het Verenigd Koninkrijk, Zweden en Zwitserland. Omdat de respons onevenwichtig was verdeeld tussen de landen, werd de dataset gewogen. Zo kreeg elk land een gelijke proportie cases in de analyse. Bovendien werd de steekproef beperkt tot steden met minstens 10.000 inwoners.

2. Dit zijn de zogenaamde "talking or brokerage professions” (Norris \& Lovenduski, 1993).

3. Voor een gedetailleerde analyse (o.a. naar het effect van lokale bestuurstraditie, gemeentegrootte en partijtype), zie Reynaert, 2012.

4. Israël vormt een uitzondering in dit onderzoek en behoort niet tot deze klassieke typologieën.

\section{Bibliografie}

Eldersveld, S., Stromberg, L. \& Derksen, W. (1995). Local Elites in Western Democracies. A Comparative Analysis of Urban Political Leaders in the U.S., Sweden and the Netherlands. Boulder, CO: Westview Press.

Norris, P. \& Lovenduski, J. (1993). 'If Only More Candidates Came Forward'. Supplyside Explanations of Candidate Selection in Britain, British Journal of Political Science, 23 (3), 373-408. 
Reynaert, H. (2012). The Social Base of Political Recruitment. A Comparative Study of Local Councillors in Europe, Lex Localis - Journal of Local Self Government, 10 (1), 19-36.

Steyvers, K. \& Reynaert, H. (2006). 'From the Few are Chosen the Few...' On the So- cial Background of European Mayors. In H. Bäck, H. Heinelt \& A. Magnier (Eds.), The European Mayor. Political Leaders in the Changing Context of Local Democracy (pp. 43-73). Wiesbaden: VS Verlag für Sozialwissenschaften. 